International Journal of Current Aspects, Volume 3, Issue II, 2019, PP 98-116, ISSN 2616-6976

[iJCAB

\title{
Effects of Devolution on Maternal Health Care: The Case of Level Four Hospitals in Nairobi City County, Kenya
}

\author{
Bulinda Hudson Shilibwa ${ }^{l}$, Felix Kiruthu, Ph.D ${ }^{2}$ \\ Correspondent Author, Department of Public Policy and Administration, Kenyatta University ${ }^{1}$ \\ Department of Public Policy and Administration, Kenyatta University ${ }^{2}$
}

ABSTRACT

Maternal healthcare is an integral part of the Millennium development goals. However, most developing countries have been experimenting with different types of interventions to increase access and utilization of maternal care services. Health care devolution was greeted with great anticipation in Kenya as a means of bringing services closer to the people. However, since the implementation of the recent devolution reforms, criticism has mounted, with evidence of corruption, poor management, late payment of county staff and considerable disaffection among service providers, especially health professionals. Thus, this study assessed the effects of devolution on maternal health care in Nairobi City County in Kenya. Particularly, the study examined the situation of maternal healthcare before and after devolution and how devolution as affected provision of maternal healthcare in Nairobi City County. The study also assessed how devolution affected maternal health care programs implementation and the challenges facing the devolved maternal health care in Nairobi City County. The study adopted the systems approach and the decentralization theorem. This study employed a descriptive research design and the population of the study was made up of the 4 level four hospitals in Nairobi County and all the 189 selected medical health workers in the hospitals. A sample of 57 respondents was selected through simple random sampling. Additionally, the study used questionnaires and an interviews guide to collect data. The questionnaires were administered to the sampled medical workers and the interviews schedules were administered to the key informants who comprised of the medical superintendent from every hospital. Quantitative data was collected through the use of the questionnaires was analyzed using descriptive statistics with the aid of the Statistical Package for Social Sciences. Qualitative data was analyzed using content analysis. The study found that the status of maternal healthcare infrastructure under devolution of health services in Nairobi was good. The findings also established that most health workers preferred that the national government should manage maternal health care infrastructure as opposed to county governments. The study further revealed that county governments had not instituted and implemented effective maternal healthcare programs formulated by the national government. Finally, the study concludes the major challenges influencing the implementation of maternal healthcare services include attitude and perception of health professionals, resistance of devolution by health workers, strikes by health workers, shortage of healthcare workers corruption and tribalism, increased pressure on hospital equipment and infrastructure and stock outs of essential commodities in the facilities affect devolved maternal health care. The study recommended that both the county and national government should work together and combine their efforts to enhance the devolved systems of healthcare so that they can enhance maternal healthcare.

Key Words: Devolution, Health Care, Maternal Health Care, Level Four Hospitals, Nairobi City County, Kenya 
DOI: DOI 10.7176/ijcab.v3iII.9, urn:nbn:de:0000ijcab.v3iII.91

Bulinda, H., \& Kiruthu, F. (2019). Effects of Devolution on Maternal Health Care: The Case of Level Four Hospitals in Nairobi City County, Kenya. International Journal of Current Aspects, 3(II), 98-116. http://journals.ijcab.org/journals/index.php/ijcab/article/view/9

\section{INTRODUCTION}

Maternal health refers to the health of women during pregnancy, childbirth, and the postpartum period. It includes the health care dimensions of family planning, preconception, prenatal, and postnatal care in order to reduce maternal morbidity and mortality (WHO, 2010).Improving maternal health is a Millennium Development Goal adopted at the 2000 Millennium Summit of the United Nations (Kengia, Igarashi \& Kawabuchi, 2013). Across the world, there are increasing efforts to improve maternal health outcomes including the reduction in maternal mortality rates, improved access to skilled care utilization during pregnancy and delivery has been one of the strategies employed to improve maternal health outcomes (Lang'at \& Mwanri, 2015). Maternal health care plays an important role in maternal mortality reduction, especially antenatal care, skilled attendance at birth and postnatal care (Mungai, 2015). However, globally, the healthcare sector is facing enormous, challenges around both development and maintenance (KPMG, 2014). Thus, systems across the globe have and are experimenting with old as well as new approaches like devolution to fix their health care systems. Health sector decentralization policies have been implemented on a broad scale throughout the developing world. Devolution of healthcare, as other types of decentralization, profoundly changes governance relations in the health system. Devolution is meant to improve performance of the health system by transferring responsibilities and authority to locally elected governments (Mabonga, 2017).

Devolution is a form of decentralization, which is defined as the process of transferring decisionmaking and implementation powers, functions, responsibilities and resources to legally constituted, and popularly elected local governments (Medhanit, 2016). Devolution has been a political response to the ills plaguing fragile and plural societies, such as, conflicts, inequalities, rent seeking, economic stagnation, corruption and inefficient use of public resources (Onyango, 2016). Devolution is premised on the rationale that institutions closest to the citizens are the most likely to meet and properly articulate needs of the citizen; this is according to a study on the Impact of Free Delivery Policy on Utilization of Maternal Health Services the devolution of health system (Nyambane, 2014). In a devolved system, local governments have clear and legally recognized geographical boundaries over which they exercise authority and within which they perform public functions (Mwatsuma \& Nyamu, 2014). Devolution has been increasingly seen and adopted worldwide as a guarantee against discretionary use of power by central elites, as well as a way to enhance the efficiency of social service provision, by allowing for a closer match between public policies and the desires and needs of local constituencies (Machira, 2015).In the United States, for instance, the primary responsibility for a number of social programs has been shifted back to the states. In the United Kingdom decentralization movements have brought about the foundation of Scotland and Wales' own parliaments; and in Italy, Spain, and other countries, there has been increasing fiscal powers for regional and local authorities (Jiménez \& Smith, 2005). In the Philippines, devolution has relatively increased resource allocation, facilitated greater citizen participation in addressing unique health needs and bolstered decision-making power at the local levels (Mabonga, 2017). According to KPMG 2013, there has been a trend in the devolution of authority in healthcare. 
In addition, Mabonga (2017) observed that in the last two decades, health sector devolution policies have been implemented on a broad scale throughout the developing world, usually as part of a broader process of political, economic, and technical reform. Devolution of health services is widely practiced throughout the world especially in the developing countries to ensure improvement in the performance of the health system, increase population access to service and the efficiency of the delivered services (Noory, 2016; Muchomba \& Karanja, 2015). The devolution of health system structure and management has been and continues to be a key issue for many countries in the achievement of health for all, and development of primary health care (Mwatsuma \& Nyamu, 2014). Devolution has been a major policy agenda item across many African countries over the last few decades and efforts to strengthen local governments have been aimed at dealing with the region's continuing problems with governance (Mohmand \& Loureiro, 2017).Since the 1990s, there has been a shift in the aims of decentralization to enhance democratization and reduce the role of central governments as well as in its form, from deconcentration to devolution (Lakshminarayanan, 2003). Devolution reforms have been put forward as the answer to many of the governance problems of emerging democracies. However, the history of decentralization reforms in Africa is full of bad examples, mostly due to the absence of meaningful local political process, over-centralization of resources, weak local revenue base, lack of local planning capacity, and limited changes in legislation and regulations (Kilonzo, Kamaara \& Magak, 2017).

Many countries in Africa have embarked on health sector reforms though the design of the reforms differs considerably (Jeppsson \& Okuonzi, 2000). Devolution is one of the most common health sector reforms initiated in developing countries in Africa (Lakshminarayanan, 2003). However, millions of women in developing countries experience life threatening and other serious health problems related to pregnancy or childbirth (Mungai, 2015).Achieving millennium development goal 5 on reducing maternal mortality and morbidity by $75 \%$ and universal access to reproductive health remains a major developmental challenge for most subSaharan African countries. Health challenges are more acute in sub-Saharan Africa compared to other developed nations. These challenges are embedded in a broader context of poverty, poorly developed infrastructure, politically instigated conflicts and disappointingly managed governmental institutions (Kibui et al., 2015).

In Kenya, the constitution identifies the decentralization process as devolution because of the existence of locally elected governors and county assembly members although minor elements of de-concentration and delegation (Taylor \& Mulaki, 2015). Initially, Kenya's health care system was largely centralized with decisions taken at $\mathrm{MOH}$ headquarters from where they were conveyed top-down through the provincial medical officers to the district level. In an effort to increase equity in access to services, health care provision was devolved to county governments (Ministry of Health, 2015).Under the new framework, responsibility for health service delivery was assigned to the counties while policy, national referral hospitals, and capacity building are the national government's responsibility (Barker et al., 2014).However, County governments inherited a sector with a mixed performance remarkable improvement stand side by side with sluggish performance (World Bank, 2014). Kenya has made significant improvements in reducing infant and under five mortality rates but MMR remains stubbornly high (Work Bank, 2014).As a signatory to most international and continental agreements on improving access to maternal health, Kenya has launched several health campaigns. The Kenyan government's commitment to improve access to quality healthcare for mothers and children is demonstrated by such initiatives as free access to maternity care available at public health facilities. However, 
public health facilities are almost non-existent and inaccessible to most mothers and their children in underserved areas such as in the urban informal settlements (Bakibinga et al., 2014). The country also failed to achieve UN Millennium Development Goal 5 (to reduce maternal deaths by 75 per cent between 1990 and 2015) and Kenyan mothers still experience many maternal health-care challenges including complications during pregnancy and childbirth (Kilonzo, Kamaara \& Magak, 2017).

A study by Nyambane, (2014) in Kenya on the impact of free delivery policy on utilization of maternal health services established that devolution of health system had been vital promoting access to health services throughout the county. Devolution of health care has addressed the issues of discrimination of areas, problems of bureaucracy, low quality health services and promoted efficiency in the delivery of health services. Machira, (2015) in her study on women's perspectives on quality of maternal healthcare services, acknowledged that the packaging and delivery of healthcare services (supply-side) reforms have to be complemented by strengthening access and utilization (demand-side) to assure quality, acceptability and effectiveness of health care services. These studies however focused on free delivery policy an initiate by the national government in Kenya and did not focus more on maternal healthcare under devolution. This necessitates a study on the effect of devolution on maternal health care in Kenya. This situation therefore creates room for future studies on the impact of devolved medical and healthcare services.

\section{STATEMENT OF THE PROBLEM}

Maternal health care is an integral part of the MDGs. However, most developing countries have been experimenting with different types of interventions to increase access and utilization of maternal care services, including, subsidies, vouchers and decentralization (Hartwig et al., 2015). As such, devolution has been advocated as a response to most healthcare ills, and nations around the world have increasingly adapted it as a strategy to improve governance and remedy institutional deficiencies which highly centralized governments have experienced (Mabonga, 2017). However, maternal mortality and morbidity continue to pose significant health burdens particularly in low and middle-income countries despite decentralization of maternal care services (Mazalale et al., 2015). Globally, statistical estimates indicate that over half a million reproductive age women (15-49 years) do not have access to proper maternal care services (Barker et al., 2014).

In Kenya, healthcare devolution was introduced to enhance the quality of care, user satisfaction, equity, and efficiency in service delivery. Health care devolution was greeted with great anticipation in Kenya as a means of bringing services closer to the people (Mwatsuma \& Nyamu, 2014).However, since the implementation of the recent devolution reforms, criticism has mounted, with evidence of corruption, poor management, late payment of county staff and considerable disaffection among service providers, especially health professionals (Kilonzo, Kamaara \& Magak, 2017). Health care devolution has since been facing plethora of challenges mostly because healthcare workers who play a significant role in achieving health objectives, were neglected during implementation (Oyugi, 2015). To date, despite the devolution of health services, Kenya falls in the quadrant of weak performers in both maternal and infant mortality (World Bank, 2014). In Nairobi County, for instance maternal and child health in Nairobi slums are worse off than the rest of Nairobi or other urban areas in Kenya according to Magadi, (2005) in his study on the determinants of utilization of maternal healthcare. 
A number of studies have explored the concept of devolved health care across the world. For instance, Grundy et al (2003) concluded that decentralization widens the decision-making space of middle level managers, enhance resource allocations from central to peripheral areas and improve the efficiency and effectiveness of health services management in Pakistan. In Kenya, Savage and Lumbasi (2016) concluded that whereas there have been increases in infrastructure, resources and changes to governing systems, the full extent of decentralization is yet to be realized. Kipruto and Letting (2017) assessed the factors influencing provision of health care in a devolved system of government and concluded that disbursement and adequacy of finances, supplies and equipment affected health care provision in a devolved system of government. However, there most studies provide a general overview of the effects of devolution on the total health care thus; there is little evidence on the effect of devolution on maternal health care. Hence, the needs to assess the effects of devolution on maternal health care in Nairobi City County in Kenya.

\section{RESEARCH OBJECTIVES}

The study was guided by the following objectives:

i. To analyze how devolution has affected infrastructure of maternal health care in Nairobi City County.

ii. To establish how devolution has affected the implementation of maternal health care programs in Nairobi City County

iii. To examine the key barriers affecting the devolution of maternal health care in Nairobi City County

\section{THEORETICAL REVIEW}

This study adopted the systems thinking approach and the decentralization theorem

\subsection{The Systems Thinking Approach}

The systems thinking approach is also referred to Systems Thinking for Health Systems Strengthening was proposed by the World Health Organization (2009). The systems thinking approach acknowledges that problems are part of the system and the component parts of a system can best be understood in the context of relationships with each other and with other systems, rather than in isolation (Bakibinga et al., 2014). The approach demands a deeper understanding of the linkages, relationships, interactions and behaviors among the elements that characterize the entire system (Savigny \& Mookherji, 2009). Systems thinking approach helps to re-orient our perspectives by expanding our understanding of the characteristics of complex adaptive systems and identifying how this learning may be applied to system problems and the creation of potential solutions (Taghreed, 2012). The systems thinking approach underscores the importance of looking at systems from a broader perspective rather than simple parts, which make up the system (Mutale et al., 2016). Anticipating how an intervention might flow through, react with, and impinge on these sub-systems is crucial and forms the opportunity to apply systems thinking in a constructive way. Systems' thinking is an essential approach for strengthening health systems, particularly in designing and evaluating interventions. Strengthening health systems provides an opportunity to develop new strategies that will enable countries to achieve targets for millennium development goals. Strong health systems are fundamental if we are to improve health outcomes and accelerate progress towards the 
Millennium Development Goals of reducing maternal and child mortality and other diseases (Savigny \& Mookherji, 2009).

The WHO health systems framework describes six building blocks as shown in figure 2.1 that may be viewed as inputs and processes aimed at delivering outputs, outcomes and impact. For instance, devolved decision-making as an input with regard to the deployment and distribution of health workers, prompt availability of logistics and equitable, high-quality services can enhance maternal health care(Dunne, 2012). Additionally, improved coordination, and the introduction of a logistics management information system for regulating $\mathrm{MCH}-$ related drugs specifically, would protect this segment of the population from incurring catastrophic expenses. The aim of the framework is to promote a common understanding of what a health system is, and in turn what strengthening it means. In this study, the systems thinking approach elaborates how the systems building blocks can be used to ensure effective and efficient maternal health care services especially in a devolved health care system.

\begin{tabular}{|c|c|c|}
\hline $\begin{array}{l}\text { System Building Blocks } \\
\text { - } \quad \text { Service Delivery } \\
\text { - Health work force } \\
\text { - Information systems } \\
\text { - } \quad \text { Medical products and } \\
\text { technologies } \\
\text { - Health financing } \\
\text { - } \quad \text { Leadership/ } \\
\text { Governance }\end{array}$ & $\begin{array}{l}\text { - Access } \\
\text { - Coverage } \\
\text { - } \text { Quality }\end{array}$ & $\begin{array}{l}\text { Functions } \\
\text { - } \quad \text { Improved health } \\
\text { (level \& equity } \\
\text { - } \quad \text { Responsiveness } \\
\text { - } \quad \text { Social and financial } \\
\text { risk protection } \\
\text { - Improved } \\
\text { efficiency }\end{array}$ \\
\hline
\end{tabular}

Figure 1: Systems Thinking Approach

\subsection{Decentralization Theorem}

The decentralization theorem was proposed by Oates (1972) on the assumption that the central government is incapable to discriminate public policy on a regional basis (Greco, 2003). The decentralization theorem states that without spillovers, a decentralized system will be preferred. Otherwise, there is a trade-off whose resolution depends on the extent of heterogeneity in tastes and the degree of spillovers. The theory assumes that, in each system, governments maximize the aggregate surplus of their constituents and that, in a centralized system, the government chooses a uniform level of public spending for each locality (Besley \& Coate, 2003). The decentralization theorem basically postulates, the grounds of economic efficiency, a presumption in favor of sub national provision of local public goods and services: given that local preferences and costs of a local public good or service are likely to vary across jurisdictions, decentralization could increase economic welfare in the society as a whole (Jiménez \& Smith, 2005). The theory also presupposes that the gains in allocative efficiency are further enhanced by the increase in competition among local governments that decentralization might bring about. Competition among the local government also increases productive efficiency as a result of the greater 
experimentation and innovation in the production of public goods and services than if those goods or services were provided by the central government (Besley \& Coate, 2003).

The major assumption of decentralization theory is that sub national governments have access to better information about local circumstances than central authorities, and therefore can use this information to tailor services and spending patterns to citizen's needs (Greco, 2003). However, although decentralization can result in greater total health gains, it may also lead to increased inequalities in health care (Jiménez \& Smith, 2005). The decentralization theorem was relevant to the study in that the potential efficiency gains from decentralizing the health services might lead to an improvement in maternal health care of the population if decentralization of health services enables an increase in the quality of health inputs, and if these health inputs adjust to the particular preferences/needs of the local citizens.

\section{CONCEPTUAL FRAMEWORK}

A conceptual framework entails forming ideas on relationships between variables in the study and showing these relationships diagrammatically (Mugenda \& Mugenda 2003). Bogdan and Biken (2003) defines conceptual framework as a basic structure that consists of certain abstracts which represents the observational the experiential and the analytical aspects of a process of system being conceived.

\section{Independent variables Dependent Variables}

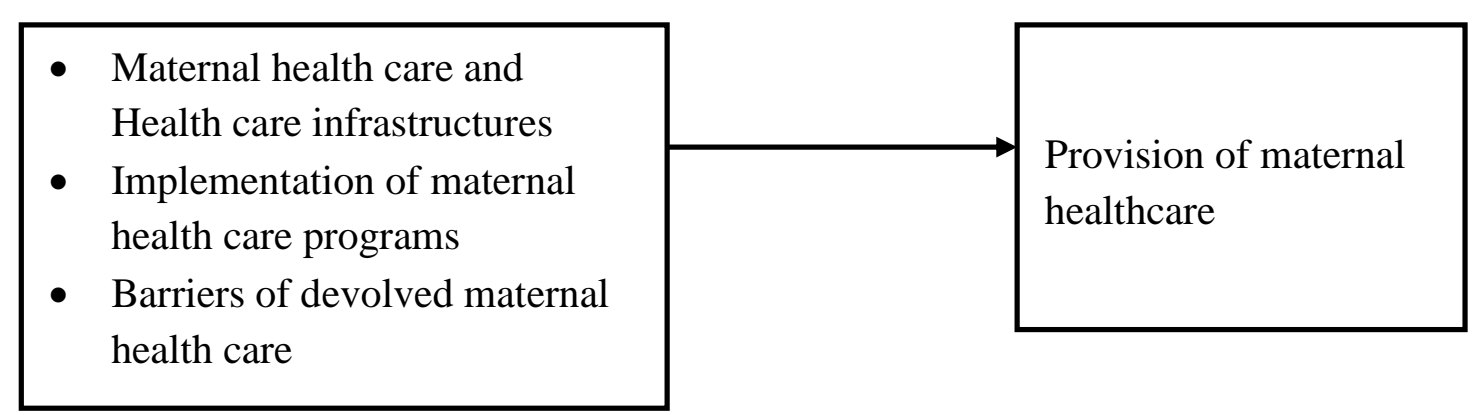

Figure 2: Conceptual Framework

\section{RESEARCH METHODOLOGY}

The study adopted a descriptive design since the design lays a greater emphasis on sample selection because the major concern is to obtain a broad picture of the social problem prevailing in the defined universe and make recommendations to bring about the desired change (Kothari, 2006). The study was carried out in Nairobi City County. Nairobi County is the biggest economic contributor to the national economy. A number of economic, political and administrative activities are undertaken in Nairobi. It is also the seat of the national government and its operations. The county borders Kiambu County to the North and West, Kajiado to the South and Machakos to the East. Among the three neighboring counties, Kiambu County shares the longest boundary with Nairobi County. The county is composed of 17 Parliamentary constituencies. In 2012, the county population was projected to be 3,517,325 and is expected to rise to 3,942,054 in 2015 and 4,253,330 in 2017. The Nairobi City County is the creation of the Constitution of Kenya 2010 and successor of the defunct City Council of Nairobi. It operates under the auspices of the Cities and Urban Areas Act, The Devolved Governments Act and a host of other acts. The Nairobi City County is charged with the responsibility of providing a variety of services to residents within its area of jurisdiction (Medhanit, 2016). 
A research population is a collection of individuals or objects/entities in a selected area. The pollution of the study was made up of the 4 level four hospitals in Nairobi County and all the 189 medical health workers in the hospitals. The hospitals included Mama Lucy Kibaki Hospital, Mbagathi District hospital, Pumwani Maternity Centre and Dagoretti Sub district hospital. This study selected a sample of 57 respondents. The respondents comprised of all medical health workers (doctors, nurses and clinical officers). The sample was $30 \%$ of the respondents as suggested by Gay et al (2006) that sample size should be at least 30 percent of the target population to achieve normal distribution and to be sufficiently representative. Sampling procedures are techniques which when used determine the number of respondents that are involved in the study to provide the necessary data that can be processed and analyzed to provide meaningful information. The sample was selected through simple random sampling where the respondents were randomly selected from each hospital. Simple random sampling was selected since it gave each respondent an equal chance of being included in the study.

The study used both primary and secondary data. Primary data was collected through the use of questionnaires and interview guides. The questionnaires were administered to the sampled medical workers with the help of two research assistants with medical background who were recruited and trained in the use of research tools prior to the execution of data collection. The interview was administered to the key informants who comprised of the medical superintendent from every hospital by the principal researcher. Secondary data included published and unpublished reports like dissertations, thesis, journal articles, books, internet materials and other relevant publication from the Ministry of Health, Nairobi City County and the government of Kenya. Secondary data was used to supplement the primary sources of data. The study collected quantitative and qualitative data. Quantitative data was collected through the use of the questionnaires was analyzed using descriptive statistics with the aid of the Statistical Package for Social Sciences (SPSS Version 21). Descriptive statistics were used to summarize the data using frequencies, percentages and the mean and was presented using frequency tables, graphs and charts. Qualitative data collected through interviews was analyzed thematically using content analysis and the findings were presented in direct quotations and selected comments.

\section{DATA ANALYSIS RESULTS}

\subsection{Devolution and Infrastructure of Maternal Health Care}

This section sought to analyze how devolution had affected the infrastructure of maternal health care in Nairobi City County. The results are presented as follows. This sought to establish to what extent infrastructure in terms of the beds, number of doctors and theatre facilities have been devolved for maternal healthcare. Table 1 shows the results

Table 1: Status of Health Care Infrastructure under Devolution

\begin{tabular}{lcc}
\hline Devolved infrastructure level & Frequency & Percent \\
\hline Excellent & 5 & 10.4 \\
Good & 21 & 43.8 \\
Average & 18 & 37.5 \\
Poor & 4 & 8.3 \\
\hline
\end{tabular}




\section{Total}

48

100.0

The findings on table 1 shows that $43.8 \%$ of the respondents indicate that the status of health care infrastructure under devolution was good, $37.5 \%, 10.4 \%$ and $8.3 \%$ indicated that it was average, excellent and poor respectively. This finding on average indicates that the status of health care infrastructure under devolution was good however, a good number of respondents indicated that the available infrastructure was average. A study by Mungai (2015) found that despite the fact that improved accessibility to referral maternal health care had increased pressure on equipment, commodities, infrastructure and personnel. The key respondents through interviews were asked to describe the status of health care infrastructure under devolution and majority indicated that the available infrastructure was good and commendable. They however preferred the Health sector would still be under the National government but still appreciated the work done by the county government. One of the medical superintendents 'A49' indicated that "county governments were not adequately prepared and lack the capacity to fully run medical services in the county". Korir (2013), in her study on challenges affecting devolution of public sector services in local authorities in Kenya, supported this observation and suggested that in order for devolution to succeed training, empowerment, mobilization of resources should be encouraged by the authorities, and systems should be established at local level to ensure the devolved services reaches the ordinary citizens.

\subsection{Preferred Level of Government to Provide Hospital Infrastructure}

This aimed at establishing which level of government the respondents preferred to provide infrastructure on maternal health care's services. Figure 3 shows the results.

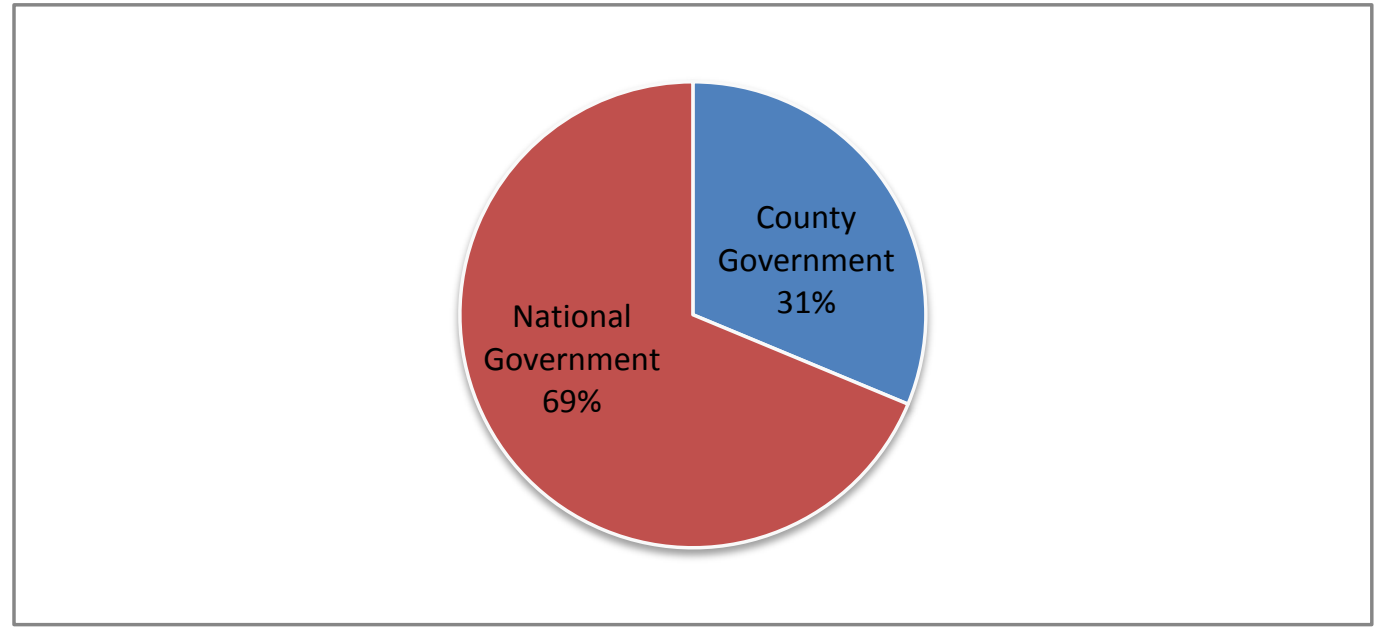

Figure 3: Level of Government Preferred to Provide Hospital Infrastructure

The results on figure 2 show that $69 \%$ of the respondents indicated that they preferred the national government to provide infrastructure on maternal healthcare services while $31 \%$ preferred the county governments. This indicates that most health workers prefer working with the national government as opposed to county governments. The respondents through interviews were asked to indicate level of government they would prefer to run maternal health care's services and indicated that they would prefer the national government but some of them indicated that the national government can partially carry out some function in conjunction with the county government before they completely devolve all services. Respondent 'A50' said that 
'the national government should run the major areas like infrastructure provision and delegate a few responsibilities to the county as such would help the county governments to grow in terms of the level of service providence to increases the customer satisfaction and trust in them'.A report by KPMG (2014) on devolution in Kenya established that although most counties face unique challenges during the devolution process some counties struggle in more areas, from inadequacies in infrastructure and equipment to poor governance. The KPMG (2014) report also found that counties that performed relatively well still had inadequate healthcare inputs according to national or international standards.

\subsection{Effectiveness of County Governments in Managing Hospital Infrastructure}

This aimed at establishing how effectively county governments are managing infrastructure on maternal healthcare services. Table 2 shows the results.

Table 2: Effectiveness of County Governments in Managing Hospital Infrastructure

\begin{tabular}{lcc}
\hline Effectiveness of county governments & Frequency & Percent \\
\hline Very Effective & 1 & 2.1 \\
Effective & 15 & 31.3 \\
Less effective & 20 & 41.7 \\
Not effective & 12 & 25.0 \\
\hline Total & $\mathbf{4 8}$ & $\mathbf{1 0 0 . 0}$ \\
\hline
\end{tabular}

The results on table 2 indicate that $41.7 \%$ of the respondents indicated that the county government was less effective while $25 \%$ indicated that it was not effective. On the other hand, $31.3 \%$ indicated that the county government was effective whereas $2.1 \%$ indicate it was very effective. On average these results indicate that the county government was less effective in managing hospital infrastructure on maternal healthcare services. The respondents through interviews were also asked to indicate whether the devolution of maternal health care services was working out effectively and indicated that it was not effective as most medical workers had not accepted working under the county government and thought that the process of devolving healthcare services was devolved and the input of medical workers was not factored. One of the Key respondents 'A52' said that 'most medical workers are of the view that county governments do not have the capacity to manage hospital infrastructure and hospital staff. Savage and Lumbasi (2016) found that due to devolution of health services there have been increases in health facilities and infrastructure, increases in health personnel, as well as improvements to maternal health care.

\subsection{Devolution and Enhancement of Maternal Health Care Infrastructure}

This sought to establish whether devolution of health services had enhanced maternal health care infrastructure in Nairobi County. Figure4.3 shows the obtained results 


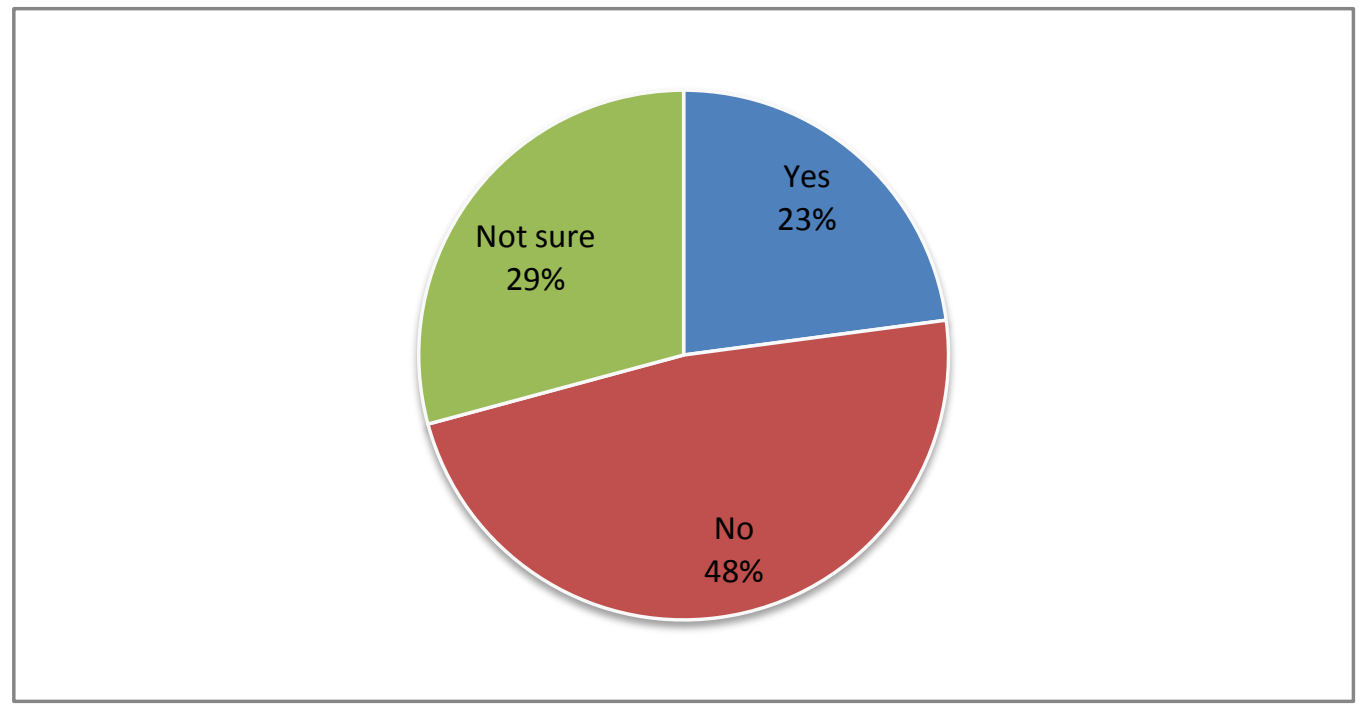

Figure 4: Devolution and Enhancement of Maternal Health Care Infrastructure

The results on figure 4 shows that $48 \%$ indicated that devolution had not enhanced maternal health care infrastructure whereas $29 \%$ of the respondents were not certain on whether devolution had enhanced maternal health care while $23 \%$ agreed that devolution had positively enhanced maternal healthcare services. On average, the finding indicates that devolution had not advanced maternal healthcare services infrastructure. A study by Muchomba and Karanja (2015) on the influence of devolution of government service delivery on provision of healthcare revealed that devolved procurement process, availability of infrastructure, resources allocation and availability as well as policy and regulatory framework had a significant influence on the performance of the level four hospitals and the overall health sector but the devolution process has not been fully implemented and its effect has not been fully experienced in the health sector

\subsection{Devolution and Maternal Health Care Programs Implementation}

This aimed at assessing how devolution has affected maternal health care programs implementation in Nairobi City County. This aimed at ascertaining whether devolution affects maternal health care programs implementation. The results are shown by table 3 .

Table 3: Devolution Effects on Maternal Health Care Programs Implementation

\begin{tabular}{|c|c|c|c|c|c|c|c|}
\hline $\begin{array}{l}\text { Devolution effects on } \\
\text { maternal health care }\end{array}$ & $\begin{array}{c}1 \\
\text { F }(\%)\end{array}$ & $\begin{array}{c}2 \\
\mathrm{~F}(\%)\end{array}$ & $\begin{array}{l}3 \underset{(\%)}{\mathbf{F}} \\
{ }^{3}\end{array}$ & $\begin{array}{c}4 \\
\text { F }(\%)\end{array}$ & $\begin{array}{l}5 \text { F } \\
(\%)\end{array}$ & Mean & $\begin{array}{l}\text { Std. } \\
\text { Dev }\end{array}$ \\
\hline $\begin{array}{l}\text { County governments have } \\
\text { instituted and implemented } \\
\text { effective maternal healthcare } \\
\text { programs to enhance deliver } \\
\text { of the essential health } \\
\text { services }\end{array}$ & $\begin{array}{c}1 \\
(2.1)\end{array}$ & $\begin{array}{c}5 \\
(10.4)\end{array}$ & $\begin{array}{c}3 \\
(6.3)\end{array}$ & $\begin{array}{c}16 \\
(33.3)\end{array}$ & $\begin{array}{l}23(47 . \\
9)\end{array}$ & 4.15 & $\begin{array}{c}1.07 \\
2\end{array}$ \\
\hline $\begin{array}{l}\text { County governments have } \\
\text { implemented all the } \\
\text { maternal health care } \\
\text { programs formulated by the } \\
\text { national government }\end{array}$ & 0 & $\begin{array}{c}7 \\
(14.6)\end{array}$ & $\begin{array}{c}1 \\
(2.1)\end{array}$ & $\begin{array}{c}18 \\
(37.5)\end{array}$ & $\begin{array}{c}22 \\
(45.8)\end{array}$ & 4.17 & $\begin{array}{c}1.03 \\
1\end{array}$ \\
\hline
\end{tabular}


International Journal of Current Aspects, Volume 3, Issue II, 2019, PP 98-116, ISSN 2616-6976

\begin{tabular}{|c|c|c|c|c|c|c|c|}
\hline $\begin{array}{l}\text { Implementation of maternal } \\
\text { healthcare programs } \\
\text { enhances accountable for } \\
\text { quality of health care, } \\
\text { affordability and } \\
\text { acceptability to all people }\end{array}$ & $\begin{array}{c}25 \\
(52.1)\end{array}$ & $\begin{array}{c}20 \\
(41.7)\end{array}$ & 0 & $3(6.3)$ & 0 & 1.60 & .792 \\
\hline $\begin{array}{l}\text { Division of roles and } \\
\text { responsibilities between } \\
\text { central and county } \\
\text { governments has affected } \\
\text { the implementation of } \\
\text { maternal healthcare } \\
\text { programs }\end{array}$ & $\begin{array}{c}13 \\
(27.1)\end{array}$ & $\begin{array}{c}35 \\
(72.9)\end{array}$ & 0 & 0 & 0 & 1.73 & .449 \\
\hline $\begin{array}{l}\text { County governments lack } \\
\text { adequate capacity to } \\
\text { implement all maternal } \\
\text { health care programs }\end{array}$ & $\begin{array}{c}8 \\
(16.7)\end{array}$ & $\begin{array}{c}33 \\
(68.8)\end{array}$ & 0 & $\begin{array}{c}7 \\
(14.6)\end{array}$ & 0 & 2.12 & .866 \\
\hline
\end{tabular}

Table 3 shows that the mean value of whether County governments had instituted and implemented effective maternal healthcare programs to enhance deliver of the essential health services and whether County governments had implemented all the maternal health care programs formulated by the national government were 4.15 and 4.17 respectively corresponding to scale value of 4 which stands for disagree. This is an indication that county governments have not instituted and implemented effective maternal healthcare programs to enhance deliver of the essential health services and have not implemented all the maternal health care programs formulated by the national government. A study by Kilonzo, Kamaara and Magak (2017) found that improved access to maternal health-care was not only linked to devolved health services but also to other developments both at the national level (health campaigns, increased mobile telephony) and county level (improved infrastructure, relocation of available fund. In addition, Mazhar and Shaikh, (2012) revealed that devolution programs assist in decision-making simplifies the management of, and augment access to, essential maternal cares services such as antenatal and postnatal care, delivery by skilled birth attendants and family planning.

The results show that the mean values of whether implementation of maternal healthcare programs enhances accountable for quality of health care, affordability, acceptability to all people and that the division of roles and responsibilities between central and county governments has affected the implementation of maternal healthcare programs were 1.60 and 1.73 which corresponds to scale value of strongly agree. This indicates that the respondents strongly agreed that implementation of maternal healthcare programs enhances accountable for quality of health care, affordability, acceptability to all people and that the division of roles and responsibilities between central and county governments has affected the implementation of maternal healthcare programs. Finally, the mean value of whether county governments lack adequate capacity to implement all maternal health care programs is 2.12 which corresponds to the scale value of agree. This is an indication that county governments lack adequate capacity to implement all maternal health care programs.

The key respondents through interviews were asked to indicate how devolution had affected the maternal health care programs implementation in Nairobi City County and indicated that devolution had not affected the implementation to a great extent as most maternal healthcare 
program are developed and funded by the national government. One the respondents' $\mathrm{A} 51^{\prime}$ ' 'indicated different counties have instituted and implemented different programs but they could not match those of the national government'. A study by Muchomba and Karanja (2015) on the effect of devolved governance on the performance of the health sector in Kenya and revealed that devolution process has not been fully implemented and its effect has not been fully experienced in the health sector.

\subsection{Devolution and Maternal Health Care Programs Implementation}

This aimed at establishing whether devolution had positively affected the provision of maternal care services in Nairobi City County. Figure 5 shows the results

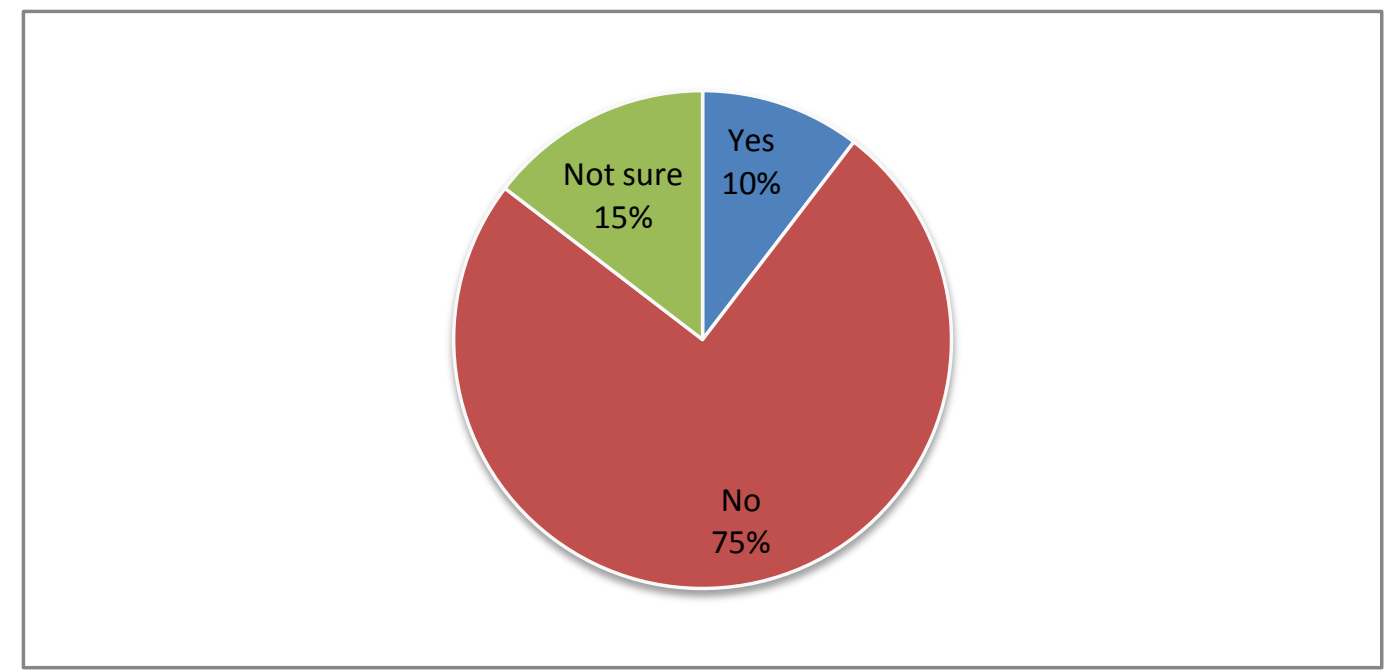

Figure 5: Devolution and Maternal Health Care Programs Implementation

Figure 5 shows that $75 \%$ of the health workers indicated that devolution had not positively affected the provision of maternal care services in Nairobi City County whereas $15 \%$ and $10 \%$ were not sure and agreed respectively. This result indicates that devolution had not positively affected the provision of maternal care services in Nairobi City County. According to the Ministry of Health (2015), devolution of health services is largely understood to mean that counties take up responsibilities to deliver essential health services whilst the central government focuses on policies and regulations.

\subsection{Barriers Affecting the Devolution of Maternal Health Care}

This section aimed at establishing the various barriers, which had affected the devolved maternal health care. Table 4 shows the results as follows

Table 4: Barriers affecting the Devolution of Maternal Health Care

\begin{tabular}{|c|c|c|c|c|c|c|c|}
\hline Challenges of devolution & $\begin{array}{c}1 \\
\text { F }(\%)\end{array}$ & $\begin{array}{c}2 \\
\text { F }(\%)\end{array}$ & $\begin{array}{c}3 \\
\mathbf{F}(\%)\end{array}$ & $\begin{array}{c}4 \\
\mathrm{~F}(\%)\end{array}$ & $\begin{array}{c}\mathbf{5} \\
\mathbf{F} \\
(\%)\end{array}$ & $\begin{array}{c}\text { Mea } \\
\text { n }\end{array}$ & $\begin{array}{l}\text { Std. } \\
\text { Dev }\end{array}$ \\
\hline $\begin{array}{l}\text { Attitude and perception of health } \\
\text { professionals }\end{array}$ & $\overline{0}$ & $\begin{array}{c}5 \\
(10.4)\end{array}$ & $\begin{array}{c}9 \\
(18.8)\end{array}$ & $\begin{array}{c}16 \\
(33.3)\end{array}$ & $\begin{array}{c}18 \\
(37.5)\end{array}$ & 4.10 & 1.000 \\
\hline Resistance of devolution by health workers & 0 & $\begin{array}{c}2 \\
(4.2)\end{array}$ & $\begin{array}{c}3 \\
(6.3)\end{array}$ & $\begin{array}{c}15 \\
(31.3)\end{array}$ & $\begin{array}{c}28 \\
(58.3)\end{array}$ & 4.44 & .796 \\
\hline
\end{tabular}


International Journal of Current Aspects, Volume 3, Issue II, 2019, PP 98-116, ISSN 2616-6976 if $C A B$

\begin{tabular}{|c|c|c|c|c|c|c|c|}
\hline $\begin{array}{l}\text { High disease burden and the changing } \\
\text { patterns of diseases }\end{array}$ & $\begin{array}{c}8 \\
(16.7)\end{array}$ & $\begin{array}{c}13 \\
(27.1)\end{array}$ & $\begin{array}{c}13 \\
(27.1)\end{array}$ & $\begin{array}{c}10 \\
(20.8)\end{array}$ & $\begin{array}{c}4 \\
(8.3)\end{array}$ & 2.77 & 1.207 \\
\hline Strikes by health workers & 0 & $\begin{array}{c}4 \\
(8.3)\end{array}$ & $\begin{array}{c}5 \\
(10.4)\end{array}$ & $\begin{array}{c}20 \\
(41.7)\end{array}$ & $\begin{array}{c}19 \\
(39.6)\end{array}$ & 4.13 & .914 \\
\hline $\begin{array}{l}\text { Inequitable distribution of available health } \\
\text { workforce }\end{array}$ & 0 & $\begin{array}{c}5 \\
(10.4)\end{array}$ & $\begin{array}{c}8 \\
(16.7)\end{array}$ & $\begin{array}{c}23 \\
(47.9)\end{array}$ & $\begin{array}{c}12 \\
(25.0)\end{array}$ & 3.88 & .914 \\
\hline Shortage of health care workers & 0 & $\begin{array}{c}3 \\
(6.3)\end{array}$ & $\begin{array}{c}4 \\
(8.3)\end{array}$ & $\begin{array}{c}21 \\
(43.8)\end{array}$ & $\begin{array}{c}20 \\
(41.7)\end{array}$ & 4.21 & .849 \\
\hline Loss of skilled workers to the private sector & $\begin{array}{c}8 \\
(16.7)\end{array}$ & $\begin{array}{c}15 \\
(31.3)\end{array}$ & $\begin{array}{c}11 \\
(22.9)\end{array}$ & $\begin{array}{c}10 \\
(20.8)\end{array}$ & $\begin{array}{c}4 \\
(8.3)\end{array}$ & 2.73 & 1.216 \\
\hline $\begin{array}{l}\text { Inequity and delays in disbursement of } \\
\text { funds }\end{array}$ & $\begin{array}{c}2 \\
(4.2)\end{array}$ & $\begin{array}{c}9 \\
(18.8)\end{array}$ & $\begin{array}{c}13 \\
(27.1)\end{array}$ & $\begin{array}{c}13 \\
(27.1)\end{array}$ & $\begin{array}{c}11 \\
(22.9)\end{array}$ & 3.46 & 1.166 \\
\hline Corruption and tribalism & 0 & $\begin{array}{c}7 \\
(14.6)\end{array}$ & $\begin{array}{c}3 \\
(6.3)\end{array}$ & $\begin{array}{c}18 \\
(37.5)\end{array}$ & $\begin{array}{c}20 \\
(41.7)\end{array}$ & 4.06 & 1.040 \\
\hline $\begin{array}{l}\text { Increased pressure on hospital equipment } \\
\text { and infrastructure }\end{array}$ & 0 & $\begin{array}{c}2 \\
(4.2)\end{array}$ & $\begin{array}{c}6 \\
(12.5)\end{array}$ & $\begin{array}{c}23 \\
(47.9)\end{array}$ & $\begin{array}{c}17 \\
(35.4)\end{array}$ & 4.19 & .799 \\
\hline $\begin{array}{l}\text { Stock outs of essential commodities in the } \\
\text { facilities }\end{array}$ & 0 & $\begin{array}{c}4 \\
(8.3)\end{array}$ & $\begin{array}{c}3 \\
(6.3)\end{array}$ & $\begin{array}{c}23 \\
(47.9)\end{array}$ & $\begin{array}{c}18 \\
(37.5)\end{array}$ & 4.15 & .875 \\
\hline
\end{tabular}

Table 4 indicates that attitude and perception of health professionals, resistance of devolution by health workers, strikes by health workers, shortage of healthcare workers corruption and tribalism, increased pressure on hospital equipment and infrastructure and stock outs of essential commodities in the facilities affect devolved maternal health care to a large extent as indicated by mean values of 4.10, 4.44, 4.13, 4.21, 4.06, 4.19 and 4.15 respectively. The results also show that inequitable distribution of available health workforce and inequity and delays in disbursement of funds affect devolved maternal health care to a moderate extent as indicated by mean values of 3.88 and 3.46 restively. The results also show that high disease burden and the changing patterns of diseases and loss of skilled workers to the private sector affect devolved maternal health care to a minimal extent as shown by mean values of 2.77 and 2.88 respectively.

The key respondents through interviews were also asked to indicate the challenges are facing the devolved maternal health care services. The respondent indicated that the key challenges included limited funding, late payment of health workers perks and salaries, conflict between medical workers and administrative of county governments, lack of support by county governments, medical workers turnover and absenteeism, lack of motivation among medical workers and work overload and inadequate staff.

These findings conform to those of Nyambane (2014) in his study on impact of free delivery policy on utilization of maternal health servicesthe devolution of health system, who indicates that health workers have opposed the move to transfer their salaries to the counties, the government insists that health being one of the devolved functions, must be handled at the county level while other challenges are still pending. The Ministry of Health (2015) indicates that limited to shortage of health care workers, loss of skilled workers to the private sector and other countries, the lack of clarity in the due process for the transfer of health care workers in between counties, promotion of health workers affects the provision of maternal healthcare services. Nyongesa et al., (2015) in a study on risk factors for maternal mortality in antenatal care states that maternal healthcare challenges include inequity and delays in disbursement to the various units with favoritism to politically correct areas may also limit health care availability and utilization. 
In addition, a study by Cook, (2017) revealed that one of the most commonly recognized problems of local or decentralized government in less developed countries is lack of resources to carry out their basic functions and services the so-called unfunded mandates or responsibility resource gap. Muchangi (2015) revealed that health workers are largely dissatisfied. Nurses and doctors' unions - whose members are protesting delayed salaries and promotions in some counties - claim health was better managed by the national government. Lang'at and Mwanri (2015) found that free maternal healthcare service provision was perceived to boost skilled care utilization during pregnancy and delivery. However, challenges including; delays in the reimbursement of funds by the government to the facilities, stock outs of essential commodities in the facilities to facilitate service provision, increased workload amidst staff shortage and lack of consultation.

\section{CONCLUSIONS}

The findings revealed that the status of health care infrastructure under devolution was good though some respondents indicated that it was average. The findings also established that most health workers preferred working with the national government as opposed to county governments. The findings also revealed that the county government was less effective in managing hospital infrastructure on maternal healthcare services and that devolution had not advanced maternal healthcare services infrastructure. The study based on these results concludes that the status of infrastructure under the county government is good despite the fact that they have not been advanced further since maternal health care was devolved. The study further revealed that county governments had not instituted and implemented effective maternal healthcare programs and had not implemented all the maternal health care programs formulated by the national government. The study therefore concludes that county governments were slow in implementing various maternal health care programs instituted by both the county and national government. Finally, the study concludes the major barriers affecting the implementation of maternal healthcare services include attitude and perception of health professionals, resistance of devolution by health workers, strikes by health workers, shortage of healthcare workers corruption and tribalism, increased pressure on hospital equipment and infrastructure and stock outs of essential commodities in the facilities affect devolved maternal health care.

\section{RECOMMENDATIONS}

The study found out that maternal health services infrastructure was much better under the national government as compared to when the services where devolved. Based on the finding, the study recommends that both the county and national government should work together and combine their efforts to enhance the devolved systems of healthcare so that they can enhance maternal healthcare. The study also made an assumption that county governments were slow in implementing various maternal health care programs instituted by both the county and national government. The study therefore recommends that county governments should speed up the implementation of maternal healthcare programs to enhance the provisions of maternal healthcare under the devolved system. Finally, the study revealed that there are several barriers influencing the implementation of maternal healthcare services. The study therefore recommends that both the national and county governments should institute policy mechanisms to mitigate the various challenges affecting the devolution of maternal healthcare services and programs. 


\section{REFERENCES}

Bakibinga, P., Ettarh, R., Ziraba, A. K., Kyobutungi, C., Kamande, E., Ngomi, N. \&Osindo, J. (2014). The effect of enhanced public- private partnerships on Maternal, Newborn and child Health Services and outcomes in Nairobi-Kenya: the PAMANECH quasiexperimental research protocol. BMJ.4: e006608. doi:10.1136/ bmjopen-2014-006608

Barker, C., Mulaki, A., Mwai, D. \& Dutta, A. (2014).Devolution of Healthcare in Kenya.Assessing County Health System Readiness in Kenya: A Review of Selected Health Inputs. Health Policy Project, USAID

Besley, T. \& Coate, S. (2003). Centralized Versus Decentralized Provision of Local Public Goods: A Political Economy Approach.Journal of Public Economics, 87, 2611- 2637

Bossert, T. J. \& Beauvais, J. C. (2002). Decentralization of Health Systems in Ghana, Zambia, Uganda and the Philippines: A Comparative Analysis of Decision Space. Health Policy Plan, 17(1), 14-31.

Crook, R. C. (2017). Democratic Decentralization, Clientelism and Local Taxation in Ghana.IDS Bulletin, 48(2), 15-29

Dunne, A. (2012). Tackling the Challenge of Human Resources for Health (HRH) Strengthening in Kenya.2012 Global Health Fellow

Gay, L. R., Mills, G. E. \&Airasian, P. (2006). Educational Research: Competencies for Analysis and Applications (8th Ed.). Upper Saddle River, NJ: Pearson.

Greco, L. G. (2003). Oates' Decentralization Theorem and Public Governance.Universit’ adeglistudi di Padova

Grundy, J., Healy, V., Gorgolon L. \&Sandig, E. (2003). Overview of Devolution of Health Services in the Philippines.Rural Remote Health, 3(2), 220 - 229

Hartwig, R., Sparrow, R., Budiyati, S., Yumma, A., Warda, N., Suryahadi, A. \&Bedi, A. (2015). Effects of Decentralized Health Care Financing on Maternal Care in Indonesia. HEFPA Working Paper. Institute of Health Policy \& Management, Erasmus University Rotterdam

Harvey, D. (2015). Ending Preventable Maternal, Newborn and Child Mortality in Mandera County, Kenya. Experiences, Challenges, Strategies, and Recommendations. Save the Children, Kenya County Programme

Hutchinson, P., Akin, J. \& Ssengooba, F. (2003). The Impacts of Decentralization on Health Behaviors in Uganda.Carolina Population Center. University of North Carolina

Jeppsson, A. \& Okuonzi, S. A. (2000).Vertical or Holistic Decentralization of the Health Sector?Experiences from Zambia and Uganda.Int J Health PlannManage., 15(4):273-89.

Jeppsson, A. (2004). Decentralization and National Health Policy Implementation in Uganda - $a$ Problematic Process. Department of Community Medicine, Malmö University Hospital

Jiménez, D. \& Smith, P. C. (2005).Decentralization of Health Care and its impact on Health Outcomes. Centre for Health Economics, University of York

Kahindi, H. S. (2013). Institutionalization of Devolved Governance Strategy by County Governments in Kenya.Unpublished Project. University of Nairobi

Kengia, J, T., Igarashi, I. \& Kawabuchi, K. (2013).Effectiveness of Health Sector Reforms in Reducing Disparities in Utilization of Skilled Birth Attendants in Tanzania.Tohoku J Exp Med., 230(4), 241-253. 
Kibui, A. W., Mugo, R. K., Nyaga, G., Ngesu L. M., Mwaniki I. N. \&Mwaniki, B. (2015). Health Policies in Kenya and the New Constitution for Vision 2030.International Journal of Scientific Research and Innovative Technology, 2(1), 127-134

Kilonzo, S., Kamaara, E. \& Magak, K. (2017). Improving Access to Maternal Health Care through Devolution in Western Kenya: Interrogating Decentralization in Africa.IDS Bulletin, 48(2), 91-108

Kipruto, A. K. \& Letting, N. (2017).Factors Influencing Provision of Health Care in a Devolved System of Government, Bungoma County, Kenya.Global Journal of Health Sciences, 2(1), $13-38,2017$

Korir, V. C. (2013). Challenges Affecting Devolution of Public Sector Services in Local Authorities in Kenya: Case of County Government of Kericho. Unpublished MBA Project.Kenyatta University

Kothari, C. R. (2006). Research Methodology: Methods and Techniques. Delhi: New Age International

KPMG (2013).Devolution of Healthcare Services in Kenya: Lessons Learnt from other Countries. KPMG Services (Proprietary) Limited

KPMG (2014).Devolution of Healthcare Services in Kenya: Conference Report. KPMG Services Proprietary Limited

Lakshminarayanan, R. (2003). Decentralization and its Implications for Reproductive Health: The Philippines Experience. Reproductive Health Matters, 11(21): 96-107.

Lang'at, E. \& Mwanri, L. (2015). Healthcare Service Providers' and Facility Administrators' Perspectives of the Free Maternal Healthcare Services Policy in Malindi District, Kenya: A Qualitative Study. Reproductive Health, 12, 59-68

Lodenstein, E. \& Dao, D. (2011) Devolution and Human Resources in Primary Healthcare in Rural Mali.Human Resources for Health, 9:15-20

Mabonga, S. (2017).Effects of Devolution on Childbirth Services in Level Four Public Hospitals in Nairobi County, Kenya.Unpublished Thesis. The Catholic University of Eastern Africa

Machira, Y. W. (2015). Integrating Social Accountability in Healthcare Delivery: Lessons Drawn from Kenya.Working paper series No. 4. Kenya School of Government

Magadi, M. (2005).Maternal and Child Health among the Urban Poor in Nairobi, Kenya. Centre for Research in Social Policy. Loughborough University

Malgo, A. (2015). The state of the referral system and how this influence maternal healthcare in the Kabarole district, Uganda: A playground for inequality and corruption. Unpublished Thesis. Utrecht University

Mazalale, J., Kambala, C., Brenner, S., Chinkhumba, J., Lohmann, J., Mathanga, D. P., Robberstad, B., Muula, A. S. \& Allegri, M. (2015). Factors associated with Delivery outside a Health Facility: Cross-Sectional Study in Rural Malawi. Tropical Medicine and International Health, 20(5), 617-626

Mazhar, A. \& Shaikh, B. T. (2013). Reforms in Pakistan: Decisive Times for Improving Maternal and Child Health. Healthcare Policy, 8(1), 24-32

McIntyre, D. \& Klugman, B. (2003). The Human Face of Decentralization and Integration of Health Services: Experience from South Africa. Reprod Health Matters, 11(21):108-19.

Medhanit L. N. (2016). Opportunities, Good Practices and Challenges of Implementing Devolution under the New Constitutional Order in Nairobi County, Kenya.Unpublished Thesis. Addis Ababa University 
International Journal of Current Aspects, Volume 3, Issue II, 2019, PP 98-116, ISSN 2616-6976

[iJCAB

Ministry of Health (2015).Devolved HRM Policy Guidelines on Human Resources for Health. Ministry of Health, Kenya

Ministry of Health (2015). Health Devolution in Kenya: Strides, Constraints and Next Steps. Devolution of Health Care Services in Kenya Conference on 9th and 10th December, 2015. Ministry of Health

Mohmand, S. K. \& Loureiro, M. (2017). Introduction: Interrogating Decentralization in Africa. IDS Bulletin, 48(2), 1-14

Muchangi, J. (2015). Kenya: What's the State of Health Under Counties? Opinion. The Star

Muchomba, F. \& Karanja, N. (2015).Influence of Devolved Governance and Performance of the Health Sector in Kenya. The Strategic Journal of Business and Change Management, 2 (51), 67-105.

Mungai, S. (2015). Determinants of Maternal Health Care Services in Kenya. Unpublished Project. University of Nairobi

Mutale, W., Balabanova, D., Chintu, N., Tembo, M. \&Ayles, H. (2016). Application of System Thinking Concepts in Health System Strengthening in Low-Income Settings:A Proposed Conceptual Framework for the Evaluation of a Complex Health System Intervention: The Case of the BHOMA intervention in Zambia. Journal of Evaluation in Clinical Practice, 22, 112-121

Mwatsuma, K. M. \& Nyamu, M. H. (2014). Devolution of Health Care System in Kenya: A Strategic Approach and its Implementation in Mombasa County, Kenya. International Journal of Advanced Research, 2(4), 263-268

Noory, B. S. M. (2016). Devolution of Health Services: A Study of the Implementation of Decentralization in Khartoum Locality, Sudan. Unpublished Dissertation. University of Oslo

Nyambane, O. C. (2014). Challenges Facing Devolution in Kenya: A Comparative Study. Accessed online on 10/5/2017 from https://www.academia.edu/9385903/Challenges_Facing_Devolution_in_Kenya_A_Comp arative_Study

Nyongesa, H., Munguti, C., Odok, C. \&Mokua, W. (2015). Perceptions of Medical Students towards Healthcare Devolution: An Online Cross-Sectional Study. Pan African Medical Journal, 20:355 doi:10.11604/pamj.2015.20.355.4714

Okech, T. C. (2016). Devolution and Universal Health Coverage in Kenya: Situational Analysis of Health Financing, Infrastructure \& Personnel. International Journal of Economics, Commerce and Management, 4(5), 1094-1110

Onyango, E. A. (2016). Response Strategies Adopted by the Ministry of Health to Challenges of Devolved Healthcare Services in Kenya.Unpublished Project. University of Nairobi

Oyugi, B. O. (2015). Potential Impact of Devolution on Motivation and Job Satisfaction of Healthcare Workers in Kenya: Lessons from Early Implementation in Kenya and Experiences of other Sub-Saharan African Countries. The Journal of Global Health Care Systems, 5(1), 1-30

Pervaiz, F., Shaikh B. T. \& Mazhar, A. (2015). Role of development partners in Maternal, Newborn and Child Health $(\mathrm{MNCH})$ programming in post-reform times: a qualitative study from Pakistan. BMJ, 5: e008665. doi:10.1136/bmjopen-2015-008665

Savage, A.\& Lumbasi, L. (2016).The Impact of Decentralization in Kenya.Unpublished Thesis. Trinity College Dublin 
Savigny, D. \& Mookherji, S. (2009). Systems Thinking for Health Systems Strengthening. World Health Organization

Sekaran, U. \& Bougie, R., (2010). Research Methods for Business A Skill Building Approach ( $5^{\text {th }}$ ed.). Chichester West Sussex UK John Wiley and Sons

Shaikh, S., Naeem, I., Nafees, A., Zahidie, A., Fatmi, Z. \&Kazi, A. (2012). Experience of Devolution in District Health System of Pakistan: Perspectives Regarding Needed Reforms. J Pak Med Assoc., 62: 28-32

Simiyu, R. S., Mweru, J. N. \& Omete, F. I. (2014). The Effects of Devolved Funding on SocioEconomic Welfare of Kenyans: A Case of Constituency Development Fund in Kimilili, (Kenya). European Journal of Accounting Auditing and Faineance Research, 2(7), 31-51

Taghreed, A. \& Savigny, D. (2012). Systems Thinking for Strengthening Health Systems in LMICs: Need for a Paradigm Shift. Health Policy Plan, 27 (suppl_4): iv1-iv3. doi: 10.1093/heapol/czs084

Taylor, W. \& Mulaki, A. (2015).Devolution of Kenya's Health System.The Role of HPP. Health Policy Project, RTI International

Troachim, W. M. K. (2008). Research Methods: Knowledge Base. Mason OH.

Tutzing, L. L., Kamanga, K., McDonagh, M., Nzoya, D. \& Phillipson, R. (2011).Harmonizing support to Reproductive Health in Kenya.DFID Human Development Resource Centre

World Bank (2014).Laying the Foundation for a Robust Health Care System in Kenya.Kenya Public Expenditure Review. World Bank Group

World Health Organization (2010). Countdown to 2015-decade report (2000-2010): Taking Stock of Maternal, Newborn and Child Survival.Geneva: WHO and UNICEF

This is an open-access article published and distributed under the terms and conditions of the $(\mathrm{ccc}) \mathrm{EY}$ Creative Commons Attribution 4.0 International License of United States unless otherwise stated. Access, citation and distribution of this article is allowed with full recognition of the authors and the source.

Authors seeking to publish with an International Peer Reviewed Journal should consider www.ijcab.org by writing to the Editor at editor@ijcab.org. List of our Journals are Available at www.ijcab.org/journals 